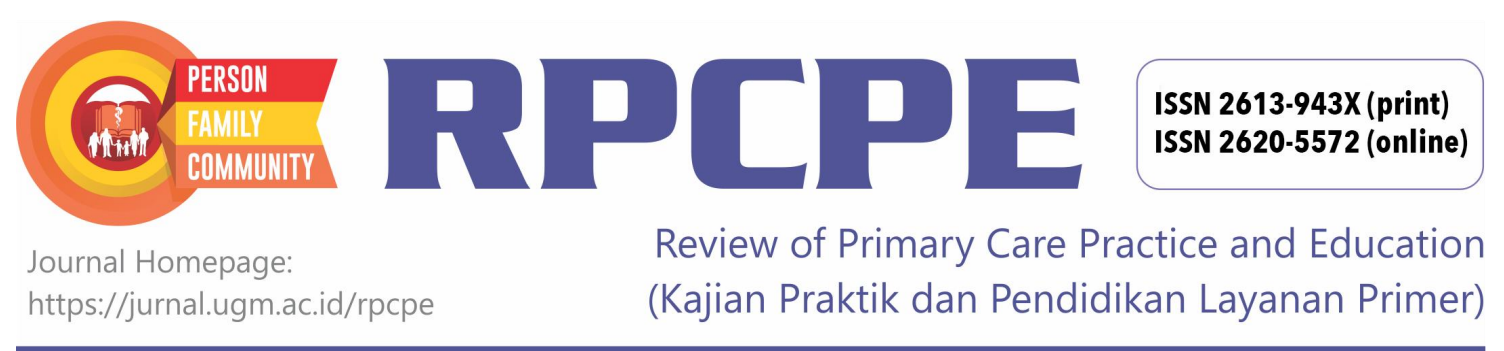

\title{
Effects of Social and Self Stigma on Adolescent Tuberculosis Patients
}

\author{
Nungki Arininta ${ }^{1}$
}

\author{
${ }^{1}$ Puskesmas Kretek; Bantul; Daerah Istimewa Yogyakarta; Indonesia \\ Corresponding Author: \\ Nungki Arininta: Puskesmas Kretek, Bantul, JL. Parangtritis, Km. 12, Sruwuh, Donotirto, Sruwuh, Donotirto, Kretek, Bantul, Bantul, \\ Daerah Istimewa Yogyakarta - 55772; Indonesia \\ Email: arinintanungki@yahoo.com \\ To cite this article: \\ Arininta N. Effects of social and self stigma on adolescent tuberculosis patients. Rev Prim Care Prac and Educ. 2019; 2(1): 43-45.
}

\section{CASE REPORT}

Patient $\mathrm{N}$ is 12 years old, suffering from positive AFB pulmonary Tuberculosis/TB (there were 3 microbes in 100 fields of view). This patient has the potential to transmit the disease to others because $\mathrm{N}$ does not want to use masks during the intensive phase of TB treatment. This is because the patient is embarrassed and afraid to be excluded from her friends. At present, the patient is a freshman in junior high school.

The patient lives with both her parents and brother. Her parents worked at odd jobs. Her younger brother is 10 years old. The last education of N's parents were junior high school graduates. This family lives in a house about $100 \mathrm{~m}^{2}$ in size. Some of the cement floors are partly ceramic and brick walls. The condition of the home environment is very windy, so some windows are covered with boards. N sleeps in rooms that do not have windows and no glass tiles, so sunlight cannot enter N's room. The condition of the house is quite clean, but in some rooms, it seems dark, windowless and not exposed to sunlight.

\section{Biological Diagnosis and Psychosocial Diagnosis}

The proportion of TB patients in children in Indonesia from 2007 to 2013 was around $7.9-12 \%$ of all cases of TB treated ${ }^{1}$. Unlike adults, whose main symptoms are coughing, the symptoms of TB in children are not typical. Weight loss, or difficult weight gain, weakness and fatigue can be symptoms of TB in children. However, children with symptoms of coughing and have sputum should be tested for sputum microscopically ${ }^{1,2}$.

TB in children is usually a primary complex consisting of primary focus in the lungs, lymphangitis and regional lymphadenitis ${ }^{2}$. Diagnosis of TB from these children usually uses a scoring system ${ }^{1,2}$. But the exact diagnosis is the discovery of Mycobacterium TB bacteria in sputum or often called positive smear, as well as the discovery of germs in gastric lavage. One of the challenges in diagnosing child TB is that child patients often have difficulty in expelling sputum $^{3}$. In this case, the patient can only expel sputum once in the morning. The results of the sputum examination were found in BTA germs in 100 fields of view.

\section{TB Transmission}

Most TB germs enter through the airways and lungs. TB germs found in droplets of $<0.5 \mathrm{um}$ can enter through the respiratory tract and reach the alveoli. In some cases, TB germs can be destroyed by a non-specific immunity. Germs that are not destroyed will be eaten by macrophages. However, a small percentage of germs cannot be destroyed by macrophages and cause macrophages to rupture. Furthermore, the TB germs will form a focus in that place called Gohn's primary focus. From this place, TB germs spread to regional lymph nodes through the lymph channels. This spreading process causes inflammation of the lymph nodes and glands. The primary focus, lymphangitis, and lymphadenitis are called the primary complex. The period of entry of TB germs until the formation of the primary complex is called the incubation period, which varies between $2-12$ weeks ${ }^{2}$.

Risk factors for transmission of childhood TB are the same as TB in general, depending on the level of transmission, length of exposure and endurance. It used to be believed that $\mathrm{TB}$ in children is not contagious because children do not have cough reflexes. However, similar to adults, pediatric TB patients with sputum containing TB germs are the source of transmission for their environment ${ }^{1,2}$. TB patients with positive smear have a transmission rate of $65 \%$. Whereas negative TB patients with positive culture results have transmission rates of $26 \%$ and negative TB patients, negative 
cultures with positive X-ray $17 \%{ }^{2}$.

\section{Problems}

The patient is currently 12 years old, who several months before being diagnosed has just entered junior high school, as a new student class VII. The patient is afraid that her friends, whom she has just known, will find out about her TB and will stay away from her. So, the patient does not want to wear a mask while at school. This, of course, will cause problems in the spread of TB in the school environment and place of residence. The patient's own mother supports the child's attitude towards the disease. Even the patient's mother is afraid that her child will be misdiagnosed.

\section{DISCUSSION}

TB is a disease that is highly contagious and can have fatal consequences, causing stigma to the community. Stigma is a negative perception. In addition to transmission factors, aspects like people's ignorance about the causes, and duration of treatment, cause stigma in society. In addition, TB is also widely believed to be a disease associated with marginalized people, for example, low social economic groups, people with HIV, people with bad environments and others. However, the stigma experienced by TB patients does not only come from family and society, but also from oneself called self-stigma ${ }^{4}$. This self-stigma or negative perception is influenced by several intrinsic factors and extrinsic factors. Intrinsic factors, including age, disposition, age, maturity, experience, physical and health. While extrinsic factors include, family, peers, environment, social culture and community norm ${ }^{5,6,7}$. This self-stigma arises due to accepted social stigma ${ }^{8}$. Selfstigma is a negative feeling from the patient that she feels socially unacceptable and creates an inferiority complex ${ }^{4}$.

Research by Cremers et al. showed $81.9 \%$ of TB patients experienced stigma. About $54 \%$ of them experience selfstigma in the form of uselessness, shame, fear, despair, guilt and ultimately lead to feelings of inferiority, feeling incomprehensible and decreasing self-efficacy, such as problem-solving abilities and decision making. This stigma also causes delays in finding TB cases, treatment in the community and increasing the spread of disease in the community ${ }^{4,5,9}$.

In this case, the patient is a teenager. The age limit for adolescents according to WHO ranges from 10-19 years. At this time, teens begin to search for identity. Teenage is a period between puberty and the completion of physical growth. Peers are very meaningful to them. Even in some cultures, adolescence is seen as a period of storms, stress, frustration, conflict, and crisis adjustments, with feelings of alienation and exclusion. Teenagers begin to pay attention to aesthetic values and moral issues ${ }^{10}$.

$\mathrm{N}$ received social stigma, first from her own mother. The patient's mother feels that TB is a disease commonly suffered by people whose homes are dirty, who does not maintain cleanliness and have low socio-economic conditions. Mrs. N (her mother) was at the denial stage after receiving her daughter's diagnosis. She suspected the laboratory results of her daughter's sputum were swapped. Her mother felt embarrassed and afraid of being shunned by her neighbors because of her daughter's illness. Mrs. N also did not want her daughter's friends to know the illness of her daughter.

This social stigma from the mother has a role in triggering the self-stigma of children. Even without suffering from $\mathrm{TB}, \mathrm{N}$ is in stormy phases. At this time, children must undergo physical changes, and during adjustments in the new school. As a result, it can be understood, $\mathrm{N}$ is afraid that if her friends find out about this illness, she will be shunned by her friends.

\section{Person Centered Care}

$\mathrm{N}$ herself needs to be explained as clearly as possible about the disease, including treatment, modes of transmission and the risk of dropping out from the treatment. Besides medical explanations, $\mathrm{N}$ also needs psychological assistance, because adolescence involves difficult times. In adolescence, there is an emotional increase, physical changes, changes in interests and roles in social life and changes in the values they embrace. This adolescence is a transitional period, where this period is the foundation of the mindset and attitude when a person matures and grows up. So, if this self-stigma is not resolved properly, it will have an effect on N's adult life.

$\mathrm{N}$ needs to be heard about her illness and what she wants. At this age, $\mathrm{N}$ also begins looking for self-identity and recognition from peers, so being different could make $\mathrm{N}$ feel inferior and ostracized by her friends of the same age. $\mathrm{N}$ needs to be boosted in self-confidence, with examples that being different does not always mean being isolated. Sometimes appearing different will cause her to be noticed and be special. To increase her confidence, $\mathrm{N}$ can be a peer counselor and TB cadre for his school when healed later.

\section{Community oriented care}

Self-stigma arises after patients are exposed to social stigma $^{8}$. In this patient, the social stigma that first arises is from the patient's mother. This is due to her ignorance of TB circumstances, which includes the causes of TB, ways of transmission, prevention methods.

So, in this case, the patient's social environment needs to get a correct explanation of TB. First of all is the closest social environment, namely the family. The family is given an understanding of the causes, modes of transmission, who can be affected, how to prevent it and about TB treatment. Families of TB patients really need to get information about TB treatment and the risks that arise if the drug is not taken according to the rules / regularly. This is because of the prolonged TB treatment, large medicine preparations, frequent side effects, which causes the importance of the family role as supervisors for the patient to take medication. Especially in this patient, the mother is still in the stage of denial and repeatedly says that her child has recovered.

After the family, counseling is given in the school environment, both to the tutors, teachers and to the 
students. At first, the patient's mother objected, when she found out the Puskesmas planned to hold counseling and screening in the patient's school. The patient's mother gave a serious message so that the school where her child is studying should not know about her child's illness. After it was explained, that coordination with the school would not name the patient, the mother finally agreed. Counseling about TB is also carried out in the village where the patient lives. After getting the correct understanding of TB, it is expected that the community understands, that anyone can get TB. Thus, it is recommended to not look down on TB patients. The correct understanding of TB is expected to cause the community to understand the method of transmission and know how to prevent it, including the ethics of coughing and mask utilization. As a result, the community can act as a supporting group for sufferers, including supervising taking medication, supporting the use of masks, without isolating patients. In the community, it needs to be explained, that this social stigma will actually harm society. Social stigma causes people to be afraid to check if there are symptoms of TB, fear, and shame in being diagnosed with $\mathrm{TB}$, so that it will become a latent danger in society ${ }^{4}$.

After the family and the social environment of the patient understand TB correctly, the source of TB transmission needs to be sought and disconnected, in the patient's family and 10 houses in the vicinity of the patient's morning and any time sputum was examined, to find the BTA.

At her school, the TB screening was done through questionnaires for all school residents. School residents who are based on a questionnaire are suspected, will be given a vial for sputum and complete sputum morning checks and at any time examinations. Counseling and school screening of patients is carried out in the former primary school and the current junior high school. This is because, patient is a new student in the current school, so there is a possibility that the patient got and transmitted TB germs to the old school. During the coordination process, counseling with the school, $\mathrm{N}$ was given a sick leave permit for 1 week.

\section{CONCLUSIONS}

Effects of social and self-stigma on patients with TB, especially those in adolescence require efforts to counsel both the family and community about TB transmission and the need to wear masks during treatment. School socialization programs can provide support for the healing process by explaining that anyone can get TB and there is a cure available.

\section{REFERENCES}

1. Anonim. Child Tuberculosis. 9 Januari 2019. Available from: www. tbindonesia.or.id/tb-anak

2. Ministry of Health of the Republic of Indonesia, Directorate General of Disease Prevention and Control. Technical guidelines for management and management of childhood TB. Jakarta: Ministry of Health of the Republic of Indonesia. 2016.

3. Ministry of Health of the Republic of Indonesia. Directorate General of Disease Control and Environmental Health. Microscopic examination of tuberculosis: A guide for laboratory staff. Jakarta: Ministry of Health of the Republic of Indonesia. 2007.

4. Sari Y. A picture of the self-stigma of a client of pulmonary tuberculosis (pulmonary TB) who is undergoing treatment at the Malingping Health Center. Media Health Sciences. 2018 Jan $1 ; 7(1): 43-50$.

5. Purwaningsih, Nihayati HE, Mu'jizah K. Perception of smear (+) TB sufferers regarding treatment with recovery status. Journal of Ners. 2017;4(2):175 - 81

6. Widayatun TR. Behavioral science. Jakarta: CV. Sagung Seto. 1999.

7. Robbins SP, TA Judge. Organizational behavior, Book 2. Jakarta: Salemba Empat. 2008.

8. Vogel DL, Wade NG, Haake S. Measuring the self-stigma associated with seeking psychological help. Journal of Counseling Psychology. 2006 Jul;53(3):325.

9. Cremers AL, de Laat MM, Kapata N, Gerrets R, KlipsteinGrobusch K, Grobusch MP. Assessing the consequences of stigma for tuberculosis patients in urban Zambia. PloS One. 2015 Mar 25;10(3):e0119861.

10. Hurlock EB, Istiwidayanti, Sijabat RM, Soedjarwo. Developmental psychology: An approach throughout the life span, 5th edition. Jakarta: Erlangga. 2003. 